\title{
EFFECT OF CHLORIDES FROM CHEMICAL DE-ICING AGENTS ON SOIL CONTAMINATION DEPENDING ON THE DISTANCE FROM ROAD AND ITS EFFECTS ON LIVING ORGANISMS
}

\author{
VILMA JANDOVÁ, MARTINA BUCKOVÁ, JITKA HEGROVÁ, JIŘÍ HUZLÍK \\ Transport Research Centre, Líšeňská 33a, 63600 Brno, Czech Republic; e-mail: vilma.jandova@cdv.cz
}

\begin{abstract}
Jandová V., Bucková M., Hegrová J., Huzlík J.: Effect of chlorides from chemical de-icing agents on soil contamination depending on the distance from road and its effects on living organisms. Ekológia (Bratislava), Vol. 39, No. 4, p. 301-309, 2020.

The article deals with the contamination of soil in the vicinity of the D1 motorway caused by the application of chemical de-icing agents in winter. In the selected area, during a period of one year (from October 2017 to October 2018), soil samples were regularly collected once a month at five different distances from the road. Chloride concentrations in aqueous extracts of the soil were monitored and the degree of toxicity was established for the selected living organisms. The resulting chloride load was evaluated with respect to the precipitation activity and the amount of de-icing salt applied in the area. The highest concentrations of chlorides were found at a distance of $2 \mathrm{~m}$ from the road. At the distance of $20 \mathrm{~m}$ from the road, the concentration of chlorides in the soil was approaching the chloride concentration found in the referential background set for the selected locality. The concentrations of chlorides at the first three measured distances from the road corresponded to the quantity of de-icing salt applied and the precipitation activity recorded during the relevant months. The maximum concentrations were reached in April 2018. Ecotoxicological testing of aqueous extracts of soil did not confirm any significant toxicity to the selected living organisms. From the tested organisms, the white mustard was identified to be the most sensitive to this type of toxicity; the increased toxicity was observed only for aqueous extracts of soil samples collected at distances $\mathrm{d}_{\mathrm{I}}(0 \mathrm{~m})$ and $\mathrm{d}_{\mathrm{II}}(1 \mathrm{~m})$, thus, it could have been related to the increased concentration of chlorides during the relevant period.
\end{abstract}

Key words: winter road maintenance, soil, chloride contamination, ecotoxicological tests.

\section{Introduction}

Road transport is one of the major factors affecting the environment. Its negative impact is manifested primarily by the production of air pollutant emissions and noise loads in the vicinity of the roads (Rashidi et al., 2019). The impact on surface and groundwater, soil and biota are also significant (Aghazadeh et al., 2012; Zítková et al., 2018). The source of contamination is materials used for road construction, vehicle operation and winter maintenance.

The application of chemical de-icing materials for the necessary winter maintenance of roads, rest areas and parking lots causes contamination of the surrounding areas by chlorides. Chlorides 
pass from roads to the surrounding soils, surface water and groundwater. Increased concentrations of chlorides in the surface runoff can cause an increased mobilization of metals $(\mathrm{Cd}, \mathrm{Cu}$, $\mathrm{Pb}$ and $\mathrm{Zn}$ ) from soil to water near roads (Bäckström et al., 2004) as well as increase the concentration of metals in groundwater. In addition, due to higher concentrations of salts in the soil environment, important cations in soils $\left(\mathrm{Al}^{3+}, \mathrm{Ca}^{2+}, \mathrm{Mg}^{2+}\right.$ and $\left.\mathrm{H}^{+}\right)$are released, which negatively influences the chemical composition of the soil (Czerniawska-Kusza et al., 2004; Löfgren, 2001). In general, it seems that river basins can remove $35-50 \%$ of chemical de-icing materials by surface runoffs, while the remaining portion of the chemicals accumulates until steady concentrations are reached in subsurface water levels (Meriano et al., 2009). The amount of chlorides in surface water and groundwater has increased in recent decades along with the increasing use of de-icing salts during the winter seasons (Kramberger, Žerovnik, 2008; Ostendorf et al., 2009; Prosser et al., 2017). Surface water affected by chemical de-icing materials, as well as soil, has a higher alkalinity than the water of the background sites (Aghazadeh et al., 2012; Bäckström et al., 2003). The alkalinisation of soil can lead to reduction of bioavailability of important nutrients, which can lead to a complete destruction of plants or forest cover (Gałuszka et al., 2011; Munck et al., 2010; Viskari, Kärenlampi, 2000). The species composition of the plant and animal communities of terrestrial and aquatic ecosystems is also altered due to the varying tolerance of the organisms to salt (Hosek, Kaufman, 1992; Vyhnálek, Dušková, 2002). The effect on vegetation is manifested by a reduction in biomass, impaired photosynthesis and cellular plasmolysis. Extremely high concentrations of chloride ions in water also have a toxic effect on some organisms (Marsalek, 2003).

The effect of winter maintenance on soil is largely detectable within approximately $10 \mathrm{~m}$ from a road (Hääl et al., 2008), with a significant decrease in chloride concentrations in the first $2 \mathrm{~m}$ from the road (Pedersen et al., 2000). In some cases, chlorides may be detected at up to $50 \mathrm{~m}$ from the road (Löfgren, 2001). This incidence may to a large degree vary according to the season. A study carried out in Denmark found that only a small amount of salt was leached from the soil environment contaminated by chlorides during the spring. The concentration of salt increased during the summer with a decreasing amount of water in the soil. In the autumn months, most of the concentrated salt was washed out due to increased precipitation. This means that, compared to other periods, the salt concentration in soil water was the highest during the period of plant growth (Pedersen et al., 2000).

The aim of the experiment was to assess the impact of chemical de-icing materials on the soil contamination at a selected location of the D1 motorway over the course of one year depending on the distance from the road. The work also included monitoring the impact of winter maintenance on selected living organisms using ecotoxicological tests.

\section{Material and methods}

To determine the level of chloride contamination and to monitor the way the concentrations of chlorides change with the increasing distance from the road, a specific site for measurements was selected at the $113^{\text {th }} \mathrm{km}$ of the D1 motorway in the direction to Prague (see Fig. 1). It is a straight section of the road without a forest cover before the exit to Jihlava $(112 \mathrm{~km})$. One of the criteria for the selection of this site was the completion of modernization of section 15 in the direction of Velký Beranov - Jihlava, which ran from August 2016 and was completed in September 2017 , that is, before we started to collect the soil samples. The modernization of section 15 continued in 2018, but it only concerned the opposite direction (Jihlava - Velký Beranov). During the modernization, the original soil was excavated from the base of the road up to the distance of approximately $10 \mathrm{~m}$ from the road and it was replaced by 


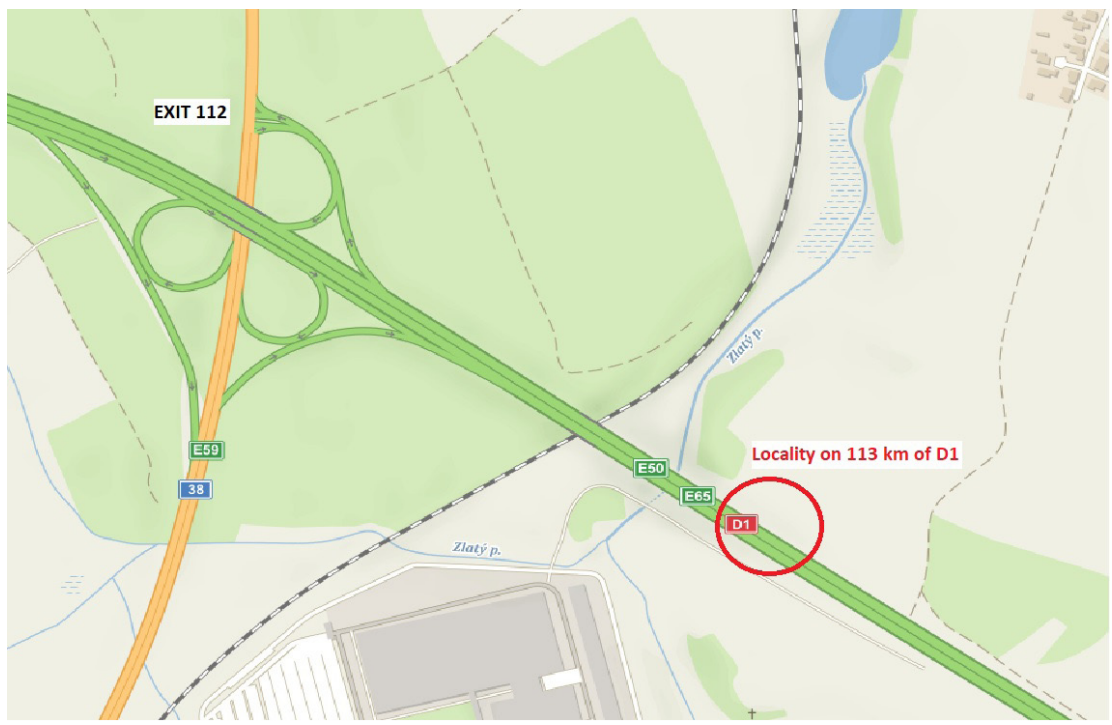

Fig. 1. Location on $113^{\text {th }} \mathrm{km}$ of D1, Prague direction.

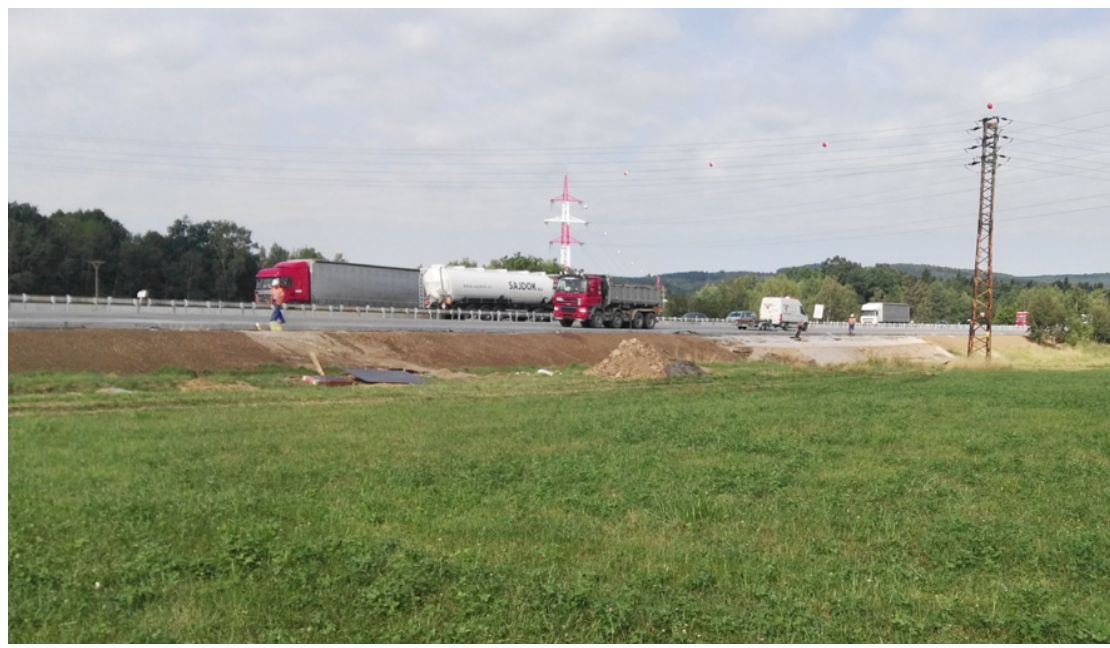

Fig. 2. Finishing works before commissioning the section in the direction of Prague in September 2017.

new soil. The locality is in the section of the motorway, which is often maintained in the winter period by chemical de-icing materials and falls under Středisko správy a údržby dálnice (SSÚD) (Centre of Administration and Maintenance of Motorway) in Velký Beranov. In the selected locality, the road is raised against the surrounding terrain, which gradually turns into a field in the direction away from the road (at the time of the monitoring, the area of the field was grassy) (see Fig. 2). 
Table 1. Distances of the sample collection sites from the road.

\begin{tabular}{|c|c|l|}
\hline $\begin{array}{c}\text { Distance } \\
\text { designation }\end{array}$ & $\begin{array}{c}\text { Distance } \\
\text { from the road }[\mathbf{m}]\end{array}$ & \multicolumn{1}{c|}{ Description } \\
\hline $\mathrm{d}_{\mathrm{I}}$ & 0 & Transition of asphalt pavement to the road shoulder \\
\hline $\mathrm{d}_{\mathrm{II}}$ & 1 & Road shoulder \\
\hline $\mathrm{d}_{\mathrm{III}}$ & 5 & Road embankment \\
\hline $\mathrm{d}_{\mathrm{IV}}$ & 20 & Surrounding of the road \\
\hline $\mathrm{d}_{\mathrm{V}}$ & 100 & Background \\
\hline
\end{tabular}

Soil samples were collected for a period of one year beginning in October 2017 until October 2018, always in regular monthly intervals from five distances in the vicinity of the road (see Table 1). During the sampling, a mixed sample of soil modified by quartering method weighing approximately $1 \mathrm{~kg}$ was collected from each monitored distance.

In a laboratory, the soil samples were first dried at room temperature and then sieved to $2 \mathrm{~mm}$ fraction according to ČSN ISO 11646 (2011). Next, an aqueous extract was prepared from the modified samples according to the procedure for extracting soils with highly purified demineralised water (Zbíral et al., 2011) in the liquid and solid-phase ratio of 101 per $1 \mathrm{~kg}$ of soil. The chloride concentrations were determined in the prepared extract using Spectroquant Prove spectrophotometer according to the laboratory's standard operating procedure. The measured concentrations of chlorides in aqueous leachates were recalculated to correspond to the concentrations in one kilogram of soil collected.

For ecotoxicological tests, the aqueous extracts of the soil samples were further modified by centrifugation and filtration through a paper filter with a mean pore size of $5 \mu \mathrm{m}$. The electrolytic conductivity and $\mathrm{pH}$ of the aqueous extracts were then measured. The effect of winter maintenance agents on living organisms was monitored by acute ecotoxicity tests on three selected organisms, namely green freshwater algae Desmodesmus subspicatus, the seeds of the white mustard Sinapis alba and water arthropod Daphnia magna. The following indicators were evaluated: for D. magna, the immobilisation of the organism was evaluated after the test duration of 48 hours; for white mustard, the inhibition or stimulation of root growth after 72 hours was measured; and for green algae, the inhibition or stimulation of cell growth after 72 hours was evaluated. The tests were carried out on aqueous extracts of the soil collected at the distances $d_{1}$ and $d_{I I}$ in each month, and the aqueous extract of soil collected at the distance $\mathrm{d}_{\mathrm{v}}$ was tested once per three months. Ecotoxicological tests were performed according to the relevant ISO standards (ČSN EN ISO 8692, 2012; ČSN EN ISO 6341, 2013) and the methodological guideline of the Czech Ministry of the Environment for the evaluation of ecotoxicity of wastes (2007).

For the period from October 2017 to October 2018, information on precipitation was also obtained from the nearest measuring station of ČHMÚ in Přibyslav, which is located approximately $13 \mathrm{~km}$ from the sampling site. Additionally, the data on the consumption of de-icing materials by the relevant SSÚDs for the period November 2017 to March 2018 were considered and recalculated to the quantity of de-icing salt used per $1 \mathrm{~km}$ of motorway.

\section{Results and discussion}

The concentrations of chlorides in the soil samples showed the highest values at the first measured distance from the road (distance $\mathrm{d}_{\mathrm{I}}$ ) (see Fig. 3), which is also confirmed by the results of another study (Pedersen et al., 2000), which states that the highest concentrations of chlorides in soils affected by winter maintenance salts are usually measured within $2 \mathrm{~m}$ of the road. More pronounced movements in the chloride concentrations were also apparent at sampling distances $\mathrm{d}_{\mathrm{II}}$ and $\mathrm{d}_{\mathrm{III}}$. Set values of chloride concentrations at distances $\mathrm{d}_{\mathrm{IV}}$ and $\mathrm{d}_{\mathrm{v}}$ fluctuated only slightly over the course of the year, remaining on approximately the same values, which were, however, one order lower than the concentrations measured at distances $\mathrm{d}_{\mathrm{I}}, \mathrm{d}_{\mathrm{II}}$ and $\mathrm{d}_{\mathrm{III}}$. It can therefore be noted that at the distance of 20 and $100 \mathrm{~m}$ from the road, the concentrations of chlorides in soils are essentially unchanging.

The chloride concentrations, focusing on the first three sampling distances closest to the road, were further compared with the quantity of de-icing salt applied per one kilometre of the mo- 
torway and the precipitation activity at the selected site. Pursuant to Decree No. 104/1997 Coll. (2018), the use of de-icing salts is carried out according to the winter maintenance plan in the period from 1 November to 31 March of the following year. As can be seen from the graphic representation in Fig. 3, the application of de-icing salt was commenced in November, its maximum was reached in January of the following year and it gradually decreased until it was completely

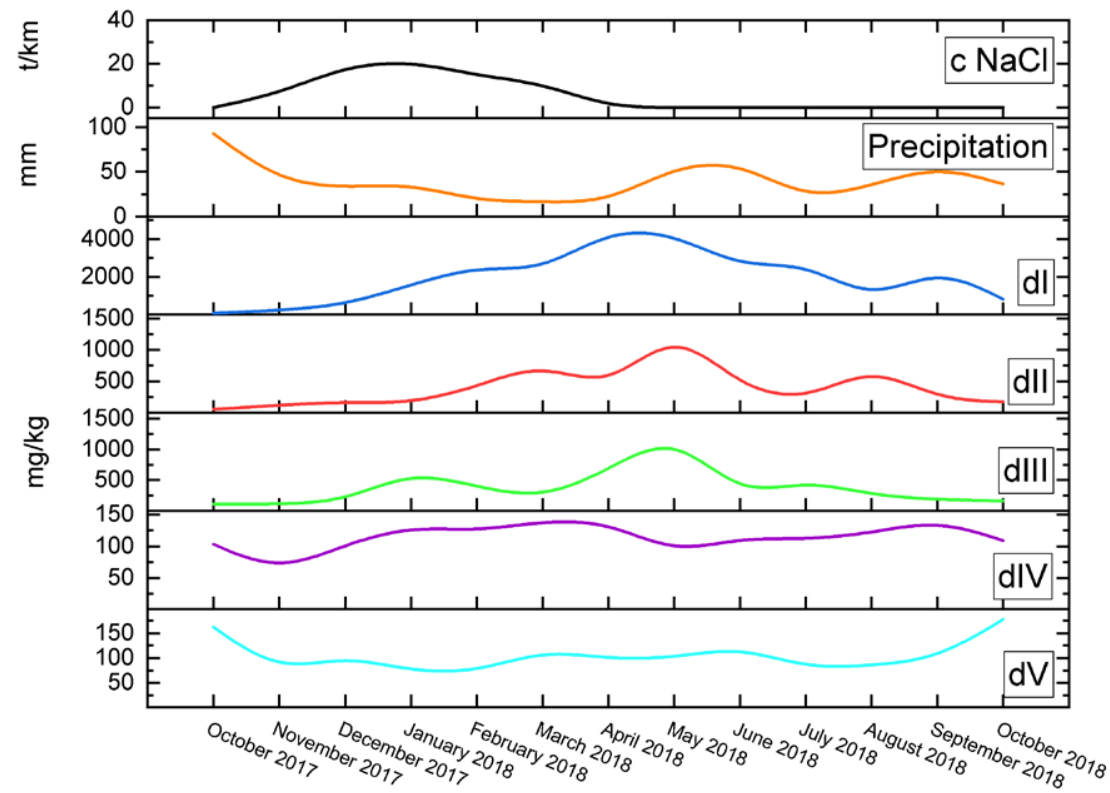

Fig. 3. Comparison of chloride concentrations at the sampling distances $d_{\mathrm{I}}-\mathrm{d}_{\mathrm{v}}$ and the quantities of de-icing salt and precipitation in the area during the period from October 2017 to October 2018.

terminated in March. The lowest concentrations of chlorides in the soil samples collected from the first three distances were recorded at the beginning of the sampling campaign in October 2017 , and ranged in values of around $80 \mathrm{mg} / \mathrm{kg}$ of soil, a value below the average of the area background concentration (distance $\mathrm{d}_{\mathrm{v}}$ ), which was set at $105 \mathrm{mg} / \mathrm{kg}$. The low concentrations were clearly caused by the fact that the soil surrounding the road was new, unloaded by chlorides, as it was brought on the site during the reconstruction of the relevant section of the D1 motorway. As the figure shows, the concentration of chlorides in the soil at the first three sampling distances increased with the increasing application of de-icing salt and it was also supported by the low precipitation in the period from November 2017 to April 2018. Thus, at the end of April, the highest concentrations of chlorides were recorded in the samples taken at the first three distances closest to the road, with the concentration values reaching up to $4000 \mathrm{mg} / \mathrm{kg}$ of soil, and at distances $\mathrm{d}_{\mathrm{II}}$ and $\mathrm{d}_{\mathrm{III}}$ approximately $1000 \mathrm{mg} / \mathrm{kg}$ of soil. With the increasing precipitation activity in May, the 
chlorides were gradually washed from the soil, which resulted in a decrease in the concentration at all three monitored distances. The decreasing trend continued until the end of the sampling period in October 2018; the maximum concentrations of chlorides in samples collected from the distances $\mathrm{d}_{\mathrm{II}}$ and $\mathrm{d}_{\mathrm{III}}$ were measured about a month later than the maximum chloride concentration in sample from distance $\mathrm{d}_{\mathrm{I}}$ due to increased precipitation. At the end of the sampling period in October 2018, the concentration values in samples from distances $d_{\text {II }}$ and $d_{\text {III }}$ decreased on average to $170 \mathrm{mg} / \mathrm{kg}$ of soil, and in samples collected from distance $\mathrm{d}_{\mathrm{I}}$ to approximately $800 \mathrm{mg} /$ $\mathrm{kg}$ of soil. Thus, compared to the background value $(105 \mathrm{mg} / \mathrm{kg}$ of soil), it is evident that the chlorides were being washed out from the soil over the course of the year due to rainfall; however, the concentration has not reached the value of the initial concentration from October 2017. A portion of the chlorides remained in the soil and accumulated; in the monitored location, this cumulation was most significant at the distance $d_{I}$ closest to the road. The conclusions described above are in line with the results of other studies (Corsi et al., 2010; Howard, Haynes, 1993), which monitored the concentrations of chlorides in the soil based on conductivity measurements. In the period from November to April, an increased conductivity in the given localities was demonstrated with high conductivity levels persisting in localities with high salt concentrations even in the period between May and October.

Soil samples collected from the first two distances closest to the road and selected background samples were further analysed using ecotoxicological tests. The conductivity values of the aqueous extract of soil collected for ecotoxicological tests correlated with the specified chloride concentrations, the highest values were measured in April and May at distance $\mathrm{d}_{\mathrm{I}}(1790$ and $1676 \mu \mathrm{S} /$ $\mathrm{cm}$ ) and the lowest conductivity values were measured in the aqueous extract of soil collected at distance $\mathrm{d}_{\mathrm{V}}$. For distances $\mathrm{d}_{\mathrm{I}}$ and $\mathrm{d}_{\mathrm{II}}$, the $\mathrm{pH}$ of the aqueous extracts of soil ranged between 8-9 with a slight increase over the course of the year (i.e., from October 2017 to October 2018). A significantly lower $\mathrm{pH}$ was measured in aqueous extracts of the background samples compared to the samples from the first two distances and it ranged around 6.

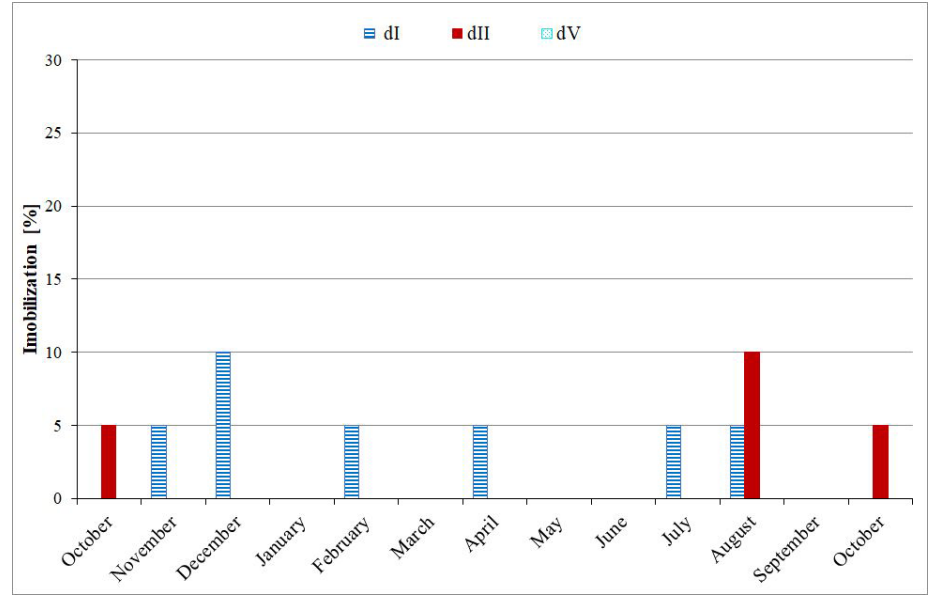

Fig. 4. Results of ecotoxicological tests for Daphnia magna.
Results from ecotoxicological tests (Figs 4,5 and 6) clearly show that from the tested organisms, the white mustard seeds have been the most responsive to the samples of aqueous extracts of soil (Fig. 5) in which increased inhibition or stimulation of root growth (greater than $20 \%$ ) was observed in the months of February to August. The values of inhibition or 
stimulation of the root growth greater than $30 \%$ were recorded only in the months of February, June, July and August, mostly in aqueous extracts of soil samples collected from distance $\mathrm{d}_{\mathrm{II}}$. These higher values may be caused by increased concentrations of chlorides as well as other substances that may be present in the extract but were not analysed within the scope of this study. When comparing the results for samples collected at distance $\mathrm{d}_{\mathrm{I}}$ and $\mathrm{d}_{\mathrm{I}}$, it cannot be clearly said at which of these distances the values of stimulation/ inhibition of the root growth are higher. For aqueous extracts of soil collected at distance $\mathrm{d}_{\mathrm{v}}$, the values of inhibition or stimulation of root growth in white mustard and cell growth

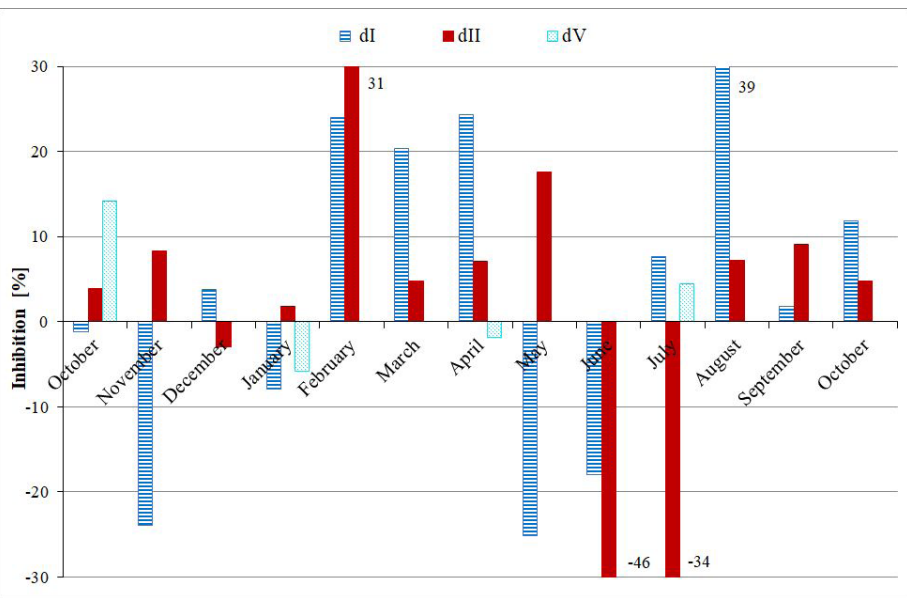

Fig. 5. Results of ecotoxicological tests for white mustard.

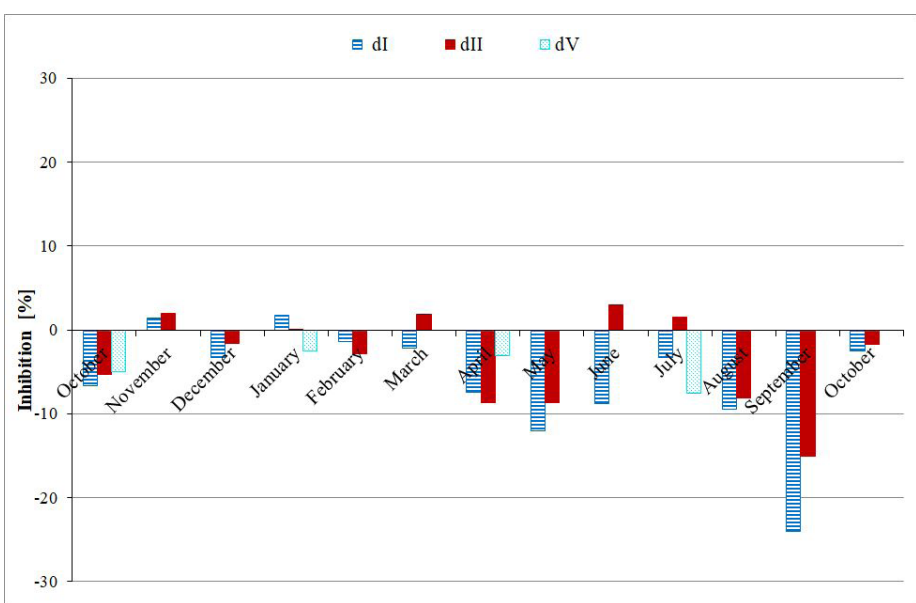

Fig. 6. Results of ecotoxicological tests for green algae. in green algae did not exceed $10 \%$. From all the tested organisms, Daphniae (Fig. 4) have responded the least to the samples. The values of immobilization of organisms ranged from $0-10 \%$, and for the background, these values were always zero. For green algae (Fig. 6), in most cases, growth stimulation was observed for up to $10 \%$, only a sample collected in September from the distances $\mathrm{d}_{\mathrm{I}}$ and $\mathrm{d}_{\mathrm{II}}$ showed a stimulation value of more than $10 \%$. The values of stimulation of green algae in the period from April to September are higher than in the period from October to March, which may be related to an increased concentration of chlorides or other substances contained in the aqueous extracts of soil collected during that period. Overall, ecotoxicological testing of aqueous soil extracts did not confirm any 
significant toxicity affecting the selected organisms. Increased toxicity was only demonstrated for the samples collected from distances $\mathrm{d}_{\mathrm{I}}$ and $\mathrm{d}_{\mathrm{II}}$, which were affecting mainly the white mustard samples.

\section{Conclusion}

Higher concentrations of chlorides in soils due to the application of de-icing salts were most apparent in samples collected from distances $\mathrm{d}_{\mathrm{I}}$ to $\mathrm{d}_{\mathrm{III}}$ closest to the road, where the highest concentrations exceeding values above $2000 \mathrm{mg} / \mathrm{kg}$ were recorded in the samples collected at distance $\mathrm{d}_{\mathrm{I}}$. The amount of chlorides at distances $\mathrm{d}_{\mathrm{I}}$ to $\mathrm{d}_{\mathrm{III}}$ is correlated with the quantity of de-icing salt applied and precipitation activity during the reference period. With low precipitation activity, the chlorides accumulate in soil; on the other hand, when the precipitation activity increases, the chlorides are gradually washed out, and thus, the concentration decreases. During the reference period, the highest amount of chlorides in the soil was recorded in the samples from the first three distances collected in April. Contents of chlorides in samples collected from distances $\mathrm{d}_{\mathrm{IV}}$ and $\mathrm{d}_{\mathrm{v}}$ were on average about $115 \mathrm{mg} / \mathrm{kg}$ of soil and $105 \mathrm{mg} / \mathrm{kg}$ of soil, respectively; the concentration of samples from distance $\mathrm{d}_{\mathrm{v}}$ is considered the background of the monitored site. It can therefore be noted that even at distance $\mathrm{d}_{\mathrm{IP}}$ the soil is essentially not affected by the application of de-icing soil during winter maintenance.

Ecotoxicological testing of aqueous extracts of soil did not confirm any significant toxicity to the selected tested organisms. From the tested organisms, the white mustard seeds appeared to be the most sensitive where higher values of inhibition or stimulation of root growth were observed for samples collected during the period from February to August at distances $\mathrm{d}_{\mathrm{I}}$ and $\mathrm{d}_{\mathrm{II}}$. These higher values may be related to the increased concentration of chlorides in the soil samples collected in this period. However, it may have been caused by higher concentrations of other substances that have not been analysed in this study. The effect of aqueous extract of the collected soil samples on green algae was predominantly stimulating, with higher stimulation values in the period between April and September 2018. For the water arthropod, Daphnia magna, the tested extracts showed zero or moderate toxicity and Daphnia is therefore considered to be the least sensitive amongst the tested organisms.

\section{Acknowledgements}

This article was created with State support of the Technology Agency of the Czech Republic within the scope of the Competence Centre programme, project CESTI (TE01020168) under research infrastructures obtained from the Operational Programme Research and Development for Innovation (CZ. 1.05/2.1.00/03.0064).

\section{References}

Aghazadeh, N., Nojavan, M. \& Mogaddam A.A. (2012). Effects of road-deicing salt ( $\mathrm{NaCl})$ and saline water on water quality in the Urmia area, northwest of Iran. Arabian Journal of Geosciences, 5(4), 565-570. DOI: 10.1007/s12517010-0210-6.

Bäckström, M., Nilsson, U., Håkansson, K., Allard, B. \& Karlsson S. (2003). Speciation of heavy metals in road runoff and roadside total deposition. Water Air Soil Pollut., 147(1-4), 343-366. DOI: 10.1023/A:1024545916834.

Bäckström, M., Karlsson, S., Bäckman, L., Folkeson, L. \& Lind B. (2004). Mobilisation of heavy metals by deicing salts in a roadside environment. Water Res., 38(3), 720-732. DOI: 10.1016/j.watres.2003.11.006. 
Corsi, S.R., Graczyk, D.J., Geis, S.W., Booth, N.L. \& Richards K.D. (2010). A fresh look at road salt: aquatic toxicity and water-quality impacts on local, regional and national scales. Environ. Sci. Technol., 44(19), 7376-7382. DOI: 10.1021/ es101333u.

Czerniawska-Kusza, I., Kusza, G. \& Dużyński M. (2004). Effect of deicing salts on urban soils and health status of roadside trees in the Opole region. Environ. Toxicol., 19(4), 296-301. DOI: 10.1002/tox.20037.

ČSN EN ISO 8692 (2012). Kvalita vod - Zkouška inhibice růstu sladkovodních zelených řas. Praha: Úřad pro technickou normalizaci, metrologii a státní zkušebnictví.

ČSN EN ISO 6341 (2013). Jakost vod - Zkouška inhibice pohyblivosti Daphnia magna Straus (Cladocera, Crustacea) Zkouška akutní toxicity. Praha: Úřad pro technickou normalizaci, metrologii a státní zkušebnictví.

ČSN ISO 11464 (2011). Kvalita půdy - Úprava vzorků pro fyzikálně-chemické rozbory. Praha: Úřad pro technickou normalizaci, metrologii a státní zkušebnictví..

Gałuszka, A., Migaszewski, Z.M., Podlaski, R., Dołegowska, S. \& Michalik A. (2011). The influence of chloride deicers on mineral nutrition and the health status of roadside trees in the city of Kielce, Poland. Environ. Monit. Assess., 176(1-4), 451-464. DOI: 10.1007/s10661-010-1596-z.

Hääl, M.-L., Sürje, P. \& Rõuk H. (2008). Traffic as a source of pollution. Estonian Journal of Engineering, 14(1), 65-82. DOI: 10.3176/eng.2008.1.05.

Hosek, J. \& Kaufman R. (1992). Vliv nákladní kamionové dopravy a zimní údržby silnice E-53 na přírodu NP Šumava a na životní prostredí centrální ćásti sídla Železná Ruda. Praha: AGNOS.

Howard, K.W.F. \& Haynes J. (1993). Groundwater contamination due to road de-icing chemicals - salt balance implications. Geoscience Canada, 20(1), 1-8. https://journals.lib.unb.ca/index.php/GC/article/view/3784

Kramberger, T. \& Žerovnik J. (2008). A contribution to environmentally friendly winter road maintenance: Optimizing road de-icing. Transportation Research, 13(5), 340-346. DOI: 10.1016/j.trd.2008.03.007.

Löfgren, S. (2001). The chemical effects of deicing salt on soil and stream water of five catchments in Southeast Sweden. Water Air Soil Pollut., 130(1/4), 863-868. DOI: 10.1023/A:1013895215558.

Marsalek, J. (2003). Road salts in urban stormwater: an emerging issue in stormwater management in cold climates. Water Sci. Technol., 48 (9), 61-70. DOI: 10.2166/wst.2003.0493.

Meriano, M., Eyles, N. \& Howard K.W.F. (2009). Hydrogeological impacts of road salt from Canada's busiest highway on a Lake Ontario watershed (Frenchman's Bay) and lagoon, City of Pickering. J. Contam. Hydrol., 107(1-2), 66-81. DOI: 10.1016/j.jconhyd.2009.04.002.

Ministry of the Environment of the Czech Republic (2007). Methodological guideline for the evaluation of ecotoxicity of waste (in Czech). Věstník Ministerstva ŽP ČR, 17(4).

Ministry of Transport and Communications of the Czech Republic. (2018). Decree No. 104/1997 Coll., Implementing the Act on Roads (in Czech). Praha: Ministerstvo dopravy a spojů.

Munck, I.A., Bennett, Ch.M., Camilli, K.S. \& Nowak R.S. (2010). Long-term impact of de-icing salts on tree health in the Lake Tahoe Basin: Environmental influences and interactions with insects and diseases. For. Ecol. Manag., 260(7), 1218-1229. DOI: 10.1016/j.foreco.2010.07.015.

Ostendorf, D.W., Palmer, R.N. \& Hinlein E.S. (2009). Seasonally varying highway de-icing agent contamination in a groundwater plume from an infiltration basin. Hydrological Research, 40(6), 520-532. DOI: 10.2166/nh.2009.062.

Pedersen, L.B., Randrup, T.B. \& Ingerslev M. (2000). Effects of road distance and protective measures on deicing $\mathrm{NaCl}$ deposition and soil solution chemistry in planted median strips. J. Arboric., 26(5), 238-245.

Prosser, R.S., Rochfort, Q., McInnis, R., Exall, K. \& Gillis P.L (2017). Assessing the toxicity and risk of salt-impacted winter road runoff to the early life stages of freshwater mussels in the Canadian province of Ontario. Environ. Pollut., 230, 589-597. DOI: 10.1016/j.envpol.2017.07.001.

Rashidi, M., Chamani, A. \& Moshtaghi M. (2019). The influence of transport infrastructure development on bird diversity and abundance. Ekológia (Bratislava), 38(2), 178-188. DOI: 10.2478/eko-2019-0014.

Viskari, E.L. \& Kärenlampi L. (2000). Roadside Scots pine as an indicator of deicing salt use - A comparative study from two consecutive winters. Water Air Soil Pollut., 122(3-4), 405-419. DOI: 10.1023/A:1005235422943.

Vyhnálek, V. \& Dušková P. (2002). Vyhodnocení analýzy chloridů v asimilačních aparátech dřevin rostoucích $v$ blízkosti solených komunikacív CHKO Blanskýles. České Budějovice: EIA SERVIS s.r.o.

Zbíral, J., Tieffová, P., Plhalová, Š., Urbánková E., Niedobová, E., Srnková, J. \& Strížová I. (2011). Analýza pưd II. Jednotné pracovní postupy. Brno: Ústřední kontrolní a zkušební ústav zemědělský, Národní referenční laboratoř.

Zítková, J., Hegrová, J. \& Anděl P. (2018). Bioindication of road salting impact on Norway spruce (Picea abies). Transport and Environment, 59, 58-67. DOI: 10.1016/j.trd.2017.12.010. 